\title{
PENGARUH ANALISIS JABATAN DAN PENGEMBANGAN KARIR TERHADAP KINERJA PEGAWAI PADAKANTOR CAMAT RANTAU SELATAN
}

\author{
Sarnama L. Tambunan ${ }^{1}$, Desmawaty Hasibuan ${ }^{2}$ \\ ${ }^{1}$ Alumni Sarjana Ekonomi STIE Labuhanbatu \\ ${ }^{2}$ Dosen STIE Labuhanbatu
}

\begin{abstract}
Abstrak : Penelitian ini bertujuan untuk mengetahui pengaruh analisis jabatan dan pengembangan karir terhadap kinerja pegawai Kantor Camat Rantau Selatan. Dan penelitian ini bertujuan untuk menganalisis indikator yang dominan terhadap kinerja pegawai. Populasi yang digunakan dalam penelitian ini adalah pegawai Kantor Camat Rantau Selatan yang bekerja pada Kantor Camat Rantau Selatan Kabupaten Labuhanbatu. Sampel yang digunakan dalam penelitian ini adalah 40 Orang dan teknik yang digunakan adalah slovin dengan metode proporsional random sampling. Metode analisis yang digunakan adalah analisis kuantitatif yaitu analisis regresi linier berganda. Analisis ini meliputi : uji validitas dan uji reliabilitas, analisis regresi linier berganda, pengajuan hipotesis melalui uji $t$ dan uji $F$ serta analisis koefisien berganda $\left(R^{2}\right)$, untuk mengetahui pengaruh variabel independen terhadap variabel dependen pada tingkat kepercayaan $95 \%$ atau $\alpha=0,05$. Hasil analisis menunjukkan bahwa analisis jabatan dan pengembangan karir terhadap kinerja pegawai Kantor Camat Rantau Selatan dengan hasil regresi berganda $\mathrm{Y}=$ $22,605+0,213 \mathrm{X}_{1}+0,166 \mathrm{X}_{2}$ yang berarti tanpa ada analisis jabatan dan pengembangan karir maka kinerja pegawai Kantor Camat Rantau Selatan tetap dengan nilai 22,605. Variabel yang paling berpengaruh yaitu analisis jabatan dengan nilai 0,186. Sedangkan nilai Koefisiensi determinasi $\left(\mathrm{R}^{2}\right)$ memberikan hasil sebesar 0,139 atau $13,9 \%$ kondisi ini menjelaskan kepuasan konsumen mampu dijelaskan oleh satu variabel independen dalam persamaan regresi berganda. Sedangkan sisanya $86,1 \%$ dijelaskan oleh variabel lain yang tidak dijelaskan.
\end{abstract}

\section{Kata kunci : Analisis Jabatan, Pengembangan Karir, dan Kinerja Pegawai.}

\section{Pendahuluan}

Dalam suatu organisasi tentu terdapat suatu tujuan yang ingin dicapai. Salah satu faktor yang mendukung dalam pencapaian tujuan tersebut adalah individu-individu atau sumber daya manusia di dalam organisasi itu sendiri. Maka Sumber Daya Manusia tersebut perlu dilakukan pengelolaan yang kemudian diarahkan untuk mencapai tujuan organisasi. Manajemen Sumber Daya Manusia menganggap bahwa karyawan adalah kekayaan atau asset utama organisasi yang harus dikelola dengan baik,

Analisis jabatan merupakan salah satu tugas manajemen untuk mendayagunakan sumber daya yang dimiliki secara optimal. Pendayagunaan ini sering berarti mengupayakan agar sumber daya manusia itu mampu dan mau bekerja secara optimal demi tercapainya tujuan organisasi. Karyawan akan mau dan mampu bekerja dengan baik bilamana ditempatkan pada posisi dan jabatan yang sesuai menurut minat dan kemampuannya. 
Analisis jabatan memang sangat penting dalam organisasi untuk menempatkan orang pada suatu jabatan atau pekerjaan tertentu. Namun kenyataannya ada organisasi yang merasa tidak perlu untuk membuat uraian jabatan dan spesifikasi jabatan karena beranggapan bahwa semua karyawan pasti tahu apa yang akan dikerjakan. Hal ini membuat kegundahan yang mendalam pada karyawan karena merasa pekerjaan yang dijalaninya tidak sesuai dengan apa yang dibayangkan, selain itu karyawan juga merasa tidak menemukan kecocokan antara pekerjaan dengan kepribadiannya sehingga evaluasi karirnya menunjukkan hasil yang tidak maksimal. Kenyataan tersebut mungkin tidak asing karena banyak organisasi yang melakukan efisiensi dengan mempekerjakan satu orang untuk beberapa bidang pekerjaan sekaligus, sehingga sulit untuk membuat uraian jabatan karena nama jabatan sering tidak nyambung dengan pekerjaan seharihari.

Selain analisis jabatan perkembangan karir juga sangat memiliki pengaruh untuk kinerja pegawai karena berkaitan posisi pekerjaan yang dimiliki seseorang selama bertahun-tahun. Ketika keahlian, keterampilan, pengalaman, dan kinerjanya meningkat, maka lambat laun akan melalui posisi yang lebih tinggi.

Saat ini, realita yang dihadapi adalah hampir semua org harus mengalami perubahan tempat bekerja beberapa kali dalam masa kerja mereka. Oleh karena itu, penekanan yang harus dilakuakan saat ini adalah memfasilitasi manajemen, pengembangan, dan analisis diri sendiri. Menyediakan perencanaan karir yang diperlukan oleh karyawan atau pegawai akan menguntungkan semua permasalahan. Perencanaan karir ini memberikan perspektif yang dibutuhkan oleh karyawan untuk memahami pilihan karir yang paling sesuai.

Perkembangan karir tidak dapat dilepaskan dari kegiatan perencanaan SDM, rekruitmen, dan seleksi dalam rangka pengaturan staf. Dari kegiatan manajemen SDM tersebut, harus diperoleh sejumlah tenaga kerja yang potensial dengan kualitas terbaik. Tenaga kerja seperti itulah yang harus diberi kesempatan untuk mengembangkan karirnya, agar kemampuannya yang terus meningkat sesuai dengan tuntutan lingkungan bisnis, tidak saja mampu mempertahankan eksistensi organisasi, tetapi juga mampu mengembangkan organisasi tersebut.

\section{Landasan Teori}

\section{Teori Tentang Analisis Jabatan}

Analisa jabatan adalah suatu kegiatan untuk mencatat, mempelajari dan menyimpulkan keterangan-keterangan atau fakta-fakta yang berhubungan dengan masing-masing jabatan secara sistematis dan teratur, misalnya Apa yang dilakukan pekerja pada jabatan tersebut, Apa wewenang dan tanggung jawabnya, Mengapa pekerjaan tersebut harus dilakukan, Bagaimana cara melakukannya, Alat-alat dan bahan-bahan yang digunakan dalam melaksanakan pekerjaannya, Besarnya upah dan lamanya jam bekerja, Pendidikan, pengalaman dan latihan yang dibutuhkan, Keterampilan, sikap dan kemampuan yang diperlukan untuk melakukan pekerjaan tersebut, Dan lain-lain.

Menurut Luis R, Gomes \& Meija Balkin, D \& Candi Robert L, (2007) Analisis jabatan adalah prosedur 
pengumpulan data yang sistematis tentang suatu jabatan dalam sebuah organisasi khususnya mengenai tugastugas dan tanggung jawab dari jabatan tersebut.

Sedangkan menurut Dessler, (2014) Analisis jabatan adalah prosedur yang dilakukan untuk menentukan tugastugas dari suatu jabatan, serta spesifikasi Sumber Daya Manusia (SDM) yang tepat untuk mengisi jabatan tersebut. Serta jelas apa yang dimaksud dengan jabatan, belum berarti bahwa permasalahannya sudah selesai. Terbatasnya pengetahuan tentang jabatan yang ada dalam perusahaan seringkali terjadi karena tidak adanya keseragaman istilah (nama jabatan) dan juga karena selalu terjadi perubahan-perubahan pada jabatan itu sendiri.

\section{Teori Tentang Perkembangan Karir}

Pengembangan karir seorang pegawai perlu dilakukan karena pegawai bekerja dalam sebuah organisasi tidak hanya ingin memperoleh apa yang dipunyanya hari ini, tetapi juga mengharapkan ada perubahan, ada kemajuan, ada kesempatan yang diberikan padanya untuk maju ke tingkat yang lebih tinggi dan lebih baik.

Menurut Sadili Samsudin (2006, dalam Isyanto dkk) mendefenidikan pengembangan karir adalah suatu usaha meningkatkan kemampuan teknis, teoritis, konseptual, dan moral karyawan sesuai dengan kebutuhan pekerjaan atau jabatan melalui pendidikan dan latihan.

Menurut Bambang Wahyudi (2008) menyebutkan defenisi dari pengembangan karir adalah suatu kondisi yang menunjukkan adanya peningkatan status seseorang dalam suatu organisasi dalam jalur karir yang telah ditetapkan dalam organisasi yang bersangkutan.

\section{Teori Tentang Kinerja Karyawan}

Secara garis besar kinerja dapat dipahami sebagai hasil kerja yang dapat dicapai oleh seseorang atau sekelompok orang dalam suatu organisasi sesuai dengan wewenang dan tanggung jawab masing-masing, guna mencapai tujuan organisasi yang bersangkutan secara legal, tidak melanggar hukum dan sesuai dengan moral maupun etika.

Menurut mangkunegara (2007), kinerja dapat didefenisikan sebagai hasil kerja secara kualitas dan kuantitas yang dapat dicapai oleh seorang pegawai dalam melaksanakan tugas sesuai dengan tanggung jawab yang diberikan kepadanya.

Istilah kinerja berasal dari kata "job performance" atau "actual performance" yaitu untuk kerja atau prestasi yang sesungguhnya dicapai oleh seseorang dalam melaksanakan tugas sesuai dengan tanggung jawab yang diberikan kepadanya.

Seseorang akan selalu mendambakan penghargaan terhadap hasil pekerjaannya dan mengharapkan imbalan yang adil. Penilaian kinerja perlu dilakukan subyektif mungkin akan memotivasi karyawan dalam melakukan kegiatannya.. disamping itu, penilaian kinerja dapat memberikan informasi untuk kepentingan pemberian gaji, 
promosi, dan pengawasan terhadap perilaku karyawan.

\section{Kerangka Konseptual}

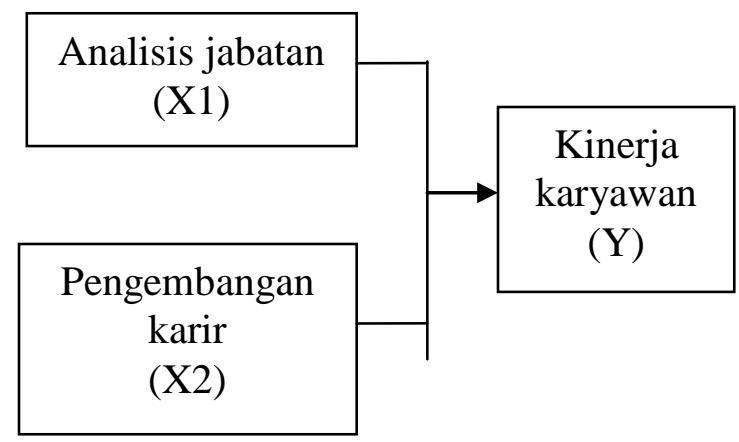

Gambar 1. Kerangka Konseptual Sumber : Hasibuan (2008)

Metode Penelitian

Tempat dan Waktu Penelitian

Penelitian dilakukan di Kantor

Camat Rantau Selatan Kabupaten

Labuhanbatu yang beralamat di jln. Dewi Sartika Rantau Selatan. Waktu penelitian ini dilakukan tiga bulan yaitu mulai bulan April sampai dengan Juni 2016.

\section{Populasi dan Sampel}

Populasi dalam penelitian ini adalah seluruh karyawan pada Kantor Camat Rantau Selatan Kabupaten Labuhanbatu, jumlah karyawan adalah 40 Orang

\section{Defenisi Operasional Variabel}

Variabel dalam penelitian ini adalah Variabel Independen atau variabel bebas (X) dan Variabel Dependen atau variabel terikat $(\mathrm{Y})$. Terdapat tiga variabel dalam penelitian ini, yaitu:

Variabel Independen

1. Analisis Jabatan $\left(\mathrm{X}_{1}\right)$

Menurut Desseler (2014) analisis jabatan adalah prosedur yang dilakukan untuk menentukan tugastugas dari suatu jabatan, serta spesifikasi SDM yang tepat untuk mengisi jabatan tersebut.

2. Pengembangan Karir $\left(X_{2}\right)$

Menurut Bambang Wahyudi (2010) pengembangan karir adalah suatu kondisi yang menunjukkan adanya peningkatan status seseorang dalam jalur karir yang telah ditetapkan dalam organisasi yang bersangkutan.

a. Variabel Independen

1. Kinerja (Y)

Menurut Hasibuan (2008) kinerja adalah suatu hasil kerja yang dicapai seseorang dalam melaksanakan tugastugasnya yang dibebankan kepadanya yang didasarkan atas kecakapan, pengalaman, kesungguhan serta waktu dalam bekerja.

\section{Jenis dan Sumber Data}

\section{Jenis data:}

Ada dua jenis data yang dikelompokkan yaitu :

1. Data Kualitatif, yaitu data yang tidak berbentuk numerik dan dapat digunakan untuk mendukung penelitian sehingga dapat menyatakan kebenarannya, (Hasibuan 2007;76)

2. Data Kuantitatif, yaitu data yang berbentuk numerik dan dapat digunakan untuk menjawab hipotesis yang diajukan (Hasibuan 2007;77)

\section{Sumber Data}

Sumber data dikelompokkan menjadi dua, yaitu :

a. Data Primer adalah data yang diperoleh secara langsung dari 
responden yang terpilih dari pada lokasi penelitian

b. Data Sekunder adalah data yang diperoleh melalui studi pustaka dengan mempelajari berbagai tulisan dari buku, jurnal, internet, dan data dari Kantor Camat Rantau Selatan Kabupaten Labuhanbatu

Skala Pengukuran Variabel

Table 1.

Instrumen Skala Likert

\begin{tabular}{|c|l|c|}
\hline No & \multicolumn{1}{|c|}{ Skala } & Skor \\
\hline 1 & Sangat Setuju (SS) & 5 \\
\hline 2 & Setuju (S) & 4 \\
\hline 3 & Kurang Setuju (R) & 3 \\
\hline 4 & Tidak Setuju (TS) & 2 \\
\hline 5 & $\begin{array}{l}\text { Sangat Tidak Setuju } \\
\text { (STS) }\end{array}$ & 1 \\
\hline
\end{tabular}

Tipe Skala Pengukuran

Skala yang digunakan yaitu skala pengukuran Likert.

\section{Teknik Pengumpulan Data}

Metode pengumpulan daya yang digunakan yaitu metode angket (kosioner) dan wawancara.

\section{Metode Analisis Data \\ Uji Validitas}

Sebelum instrumen penelitian digunakan untuk mengumpulkan data perlu dilakukan pengujian validitas. Hal ini digunakan untuk mendapatkan data yang valid dari instrumen yang valid. Menurut Sugiono (2012:12) "hasil penelitian yang valid bila terdapat kesamaan antara data yang terkumpul dengan data yang sesungguhnya terjadi pada objek yang diteliti".

\section{Uji Reliabilitas}

Reliabilitas adalah alat unutk mengukur suatu koisioner yang merupakan indikator dari variabel atau konstruk (Ghozali, 2009 : 45) $\mathrm{Y}=\mathrm{a}+\mathrm{b} 1 \mathrm{X} 1+\mathrm{b} 2 \mathrm{X} 2+\mathrm{e}$

Keterangan:

Y : Kinerja Pegawai

A : Nilai Kostanta

X1 : Variabel Analisis Jabatan

X2 :Variabel Pengembangan Karir

b1 : Koefisien Regresi Analisis Jabatan

b2 : Koefisien regresi Pengembangan Karir

e : Standar eror

\section{Hasil Penelitian}

Sejalan dengan perkembangan pertumbuhan penduduk, perekonomian, tuntutan masyarakat terhadap pelayanan publik maka kota Rantauprapat sebagai pusat Ibukota Kabupaten telah berkembang begitu pesat walaupun saat itu masih dalam 1 (satu) Kecamatan dengan Bilah Hulu. Disamping itu terjadi perubahan paradigma sistem pemerintah Daerah dalam Negara Kesatuan Republik Indonesia.

Menyikapi perkembangan dan perubahan dimaksud, Pemerintah Daerah mengusulkan pembentukan kota Administratif kepada Pemerintah Pusat dan pada Tahun 1991 maka dibentuklah melalui Peraturan Pemerintah No. 62 Tahun 1991, tentang pembentukan Kota Administratif Rantauprapat dengan wilayah 2 (dua) Kecamatan yaitu Kecamatan Rantau Utara dan Kecamatan Rantau Selatan. 
Kecamatan Rantau Selatan memiliki luas wilayah $64,34 \mathrm{~km}^{2}$ yang miliki batas sebelah utara berbatasan dengan Kecamatan Bilah Barat, sebelah timur berbatasan dengan Kecamatan Bilah Hulu, sebelah salatan berbatasan dengan Kecamatan Bilah Hulu, dan sebelah barat berbatasan dengan Kecamatan Rantau Utara.

Kecamatan Rantau Selatan terbagi dalam 9 (sembilan) Kelurahan yaitu, Kelurahan Urung Kompas, Kelurahan Bakaran Batu, Kelurahan Sioldengan Kelurahan Ujung Bandar, Kelurahan Lobusona, Kelurahan Pardamean, Kelurahan Sigambal, Kelurahan Sidorejo, Kelurahan Danau Balai.

\section{Karakteristik Penelitian}

Untuk mengetahui karakteristik responden penelitian dapat di uraikan sebagai berikut :

\section{Karakteristik Responden Berdasarkan} Jenis Kelamin

Komposisi responden menurut jenis kelamin secara rinci berikut ini:

Tabel 2.

Karakteristik Responden Berdasarkan Jenis Kelamin

\begin{tabular}{|c|l|c|c|}
\hline No & \multicolumn{1}{|c|}{$\begin{array}{c}\text { Jenis } \\
\text { Kelamin }\end{array}$} & $\begin{array}{c}\text { Frekue- } \\
\text { nsi }\end{array}$ & $\begin{array}{c}\text { Presen- } \\
\text { tase }(\boldsymbol{\%})\end{array}$ \\
\hline 1 & Laki-laki & 21 & 52,5 \\
\hline 2 & Perempuan & 11 & 27,5 \\
\hline \multicolumn{2}{|c|}{ Total } & $\mathbf{4 0}$ & $\mathbf{1 0 0}$ \\
\hline
\end{tabular}

Sumber : Data diolah (2016)

Berdasarkan tabel 4.1 mengenai karakteristik responden berdasarkan jenis kelamin paling dominan pada penelitian ini adalah laki-laki sebanyak 21 orang atau $52,5 \%$ dan responden perempuan sebanyak 11 orang atau $27,5 \%$.

\section{Karakteristik Respoden Berdasarkan Usia}

Tabel 3.

Karakteristik Responden berdasarkan Usia

\begin{tabular}{|c|l|c|c|}
\hline No & \multicolumn{1}{|c|}{ Usia } & Frekuensi & $\begin{array}{c}\text { Presen- } \\
\text { tase }(\mathbf{\%})\end{array}$ \\
\hline 1 & $\begin{array}{l}21-30 \\
\text { Tahun }\end{array}$ & 5 Orang & 12,5 \\
\hline 2 & $\begin{array}{l}31-40 \\
\text { Tahun }\end{array}$ & 6 Orang & 15 \\
\hline 3 & $\begin{array}{l}41-50 \\
\text { Tahun }\end{array}$ & 12 Orang & 30 \\
\hline 4 & $\begin{array}{l}50 \text { Tahun } \\
>\end{array}$ & 7 Orang & 17,5 \\
\hline \multicolumn{2}{|c|}{ Total } & 40 Orang & $\mathbf{1 0 0}$ \\
\hline
\end{tabular}

Sumber : Data diolah (2016)

Berdasarkan tabel 4.2 mengenai karakteristik responden berdasarkan usia paling dominan pada penelitian ini adalah usia 41-50 tahun sebanyak 12 orang atau $30 \%$ dan responden terkecil adalah usia 21-30 tahun sebanyak 5 orang atau $12,5 \%$.

Karakteristik Responden Berdasarkan Tingkat Pendidikan

Tabel 4.

Karakteristik Responden Berdasarkan Tingkat Pendidikan

\begin{tabular}{|c|l|c|c|}
\hline No & Pendidikan & Frekuensi & $\begin{array}{c}\text { Presen- } \\
\text { tase (\%) }\end{array}$ \\
\hline 1 & SD & & \\
\hline 2 & $\begin{array}{l}\text { SMA } \\
\text { Sederajat }\end{array}$ & 15 & 37,5 \\
\hline 3 & D I - III & 11 & 27,5 \\
\hline 4 & S I - S II & 14 & 35 \\
\hline \multicolumn{2}{|c|}{ Total } & $\mathbf{4 0}$ & $\mathbf{1 0 0}$ \\
\hline
\end{tabular}

Sumber : Data diolah (2016) 
Berdasarkan tabel 4.3 mengenai karakteristik responden berdasarkan tingkat pendidikan paling dominan pada penelitian ini adalah SMA Sederajat yaitu sebanyak 15 orang atau 37,5\% dan responden terkecil yaitu DI-DIII sebanyak 11 orang atau $27,5 \%$.

\section{Pembahasan}

Berdasarkan analisis data pada penelitian ini dapat diketahui bahwa analisis jabatan mempunyai pengaruh yang positif terhadap kinerja pegawai. Hal ini ditunjukkan dari hasil uji parsial terlihat bahwa nilai $t_{\text {hitung }}$ untuk variabel analisis jabatan sebesar 0,186 dengan nilai signifikan 0,271. Sedangkan untuk unnilai $t_{\text {tabel }}$ pada statistik distribusi $t$ dengan level of significance $(\alpha=0,05)$ maka df sebesar 2,026. Berdasarkan kriteria bahwa $t_{\text {hitung }}<\mathrm{t}_{\text {tabel }}$ yakni $(0,186<$ 2,026) sehingga dapat disimpulkan bahwa secara parsial variabel analisis jabatan berpengaruh secara positif dan tidak signifikann terhadap kinerja pegawai pada Kantor Camat Rantau Selatan.

Secara parsial analisis jabatan berpengaruh positif terhadap kinerja pegawai Kantor Camat Rantau Selatan Kabupaten Labuhanbatu, karena memperoleh signifikan lebih besar dari 0,05 sehingga $\mathrm{Ha}$ berbunyi "analisis jabatan berpengaruh secara signifikan terhadap kinerja pegawai" dapat diterima. Hal ini menunjukkan bahwa dengan adanya analisis jabatan maka akan meningkatkan kinerja pegawai sedangkan dengan analisis jabatan yang tidak sesuai akan berpengaruh negatif terhadap kinerja pegawai.

Disamping analisis jabatan, perkembangan karir juga berpengaruh terhadap kinerja pegawai. Berdasarkan analisis data pada penelitian ini dapat diketahui bahwa perkembangna karir mempunyai pengaruh yang positif terhadap kinerja pegawai. Hal ini ditunjukkan dari hasil uji parsial terlihat bahwa nilai thitung untuk variabel perkembangan karir sebesar 0,129 dengan nilai signifikan 0,443. Sedangkan untuk unnilai $t_{\text {tabel }}$ pada statistik distribusi $t$ dengan level of significance $(\alpha=0,05)$ maka df sebesar 2,026. Berdasarkan kriteria jika $t_{\text {hitung }}<\mathrm{t}_{\text {tabel }}$ yakni $(0,129<$ 0,443) sehingga dapat disimpulkan bahwa secara parsial variabel perkembangan karir berpengaruh secara positif dan tidak signifikann terhadap kinerja pegawai pada Kantor Camat Rantau Selatan.

Secara parsial perkembangan karir berpengaruh terhadap kinerja pegawai Kantor Camat Rantau Selatan, karena memperoleh signifikan diatas 0,05 sehingga Ha berbunyi "terdapat pengaruh perkembangan karir terhadap kinerja pegawai" dapat diterima. Hal ini menunjukkan bahwa dengan adanya perkembangan karir yang meninggak akan memperoleh kinerja pegawai yang baik pula sedangkan tanpa adanya perkembangan karir maka kinerja pegawai akan menurun dan tidak semangat dalam bekerja.

Hasil penelitian menunjukkan analisis jabatan dan perkembangan karir secara simultan maupun parsial 
berpengaruh positif dan tidak signifikan terhadap kinerja pegawai Kantor Camat Rantau Selatan Kabupaten Labuhanbatu. Hasil analisis dan uji simultan menunjukkan bahwa analisis jabatan dan perkembangan karir secara bersama-sama mempunyai pengaruh terhadap kinerja sebesar 13,9\%. Dengan demikian dapat dijelaskan bahwa selain analisis jabtan dan perkembangan karir, kinerja pegawai juga ikut ditentukan oleh faktor lain yang tidak dikaji dalam penelitian ini sebesar $86,1 \%$. Selain analisis jabatan dan perkembangan karir masih terdapat faktor lain yang juga mempengaruhi kinerja pegawai. Misalnya saja meskipun analisis jabatan sudah terlaksana dengan baik tetapi pelatihan kerja kurang, maka kinerja pegawai dapat menjadi kurang optimal. Meskipun perkembangan karir baik namun tidak di dukung dengan fasilitas lain yang memadai, maka kinerja pegawai juga kurang optimal. Agar kita dapat mencapai kinerja pegawai yang maksimal, maka kita harus memahami faktor-faktor yang mempengaruhi kinerja pegawai tersebut. Kinerja pegawai akan semakin meningkat ketika faktor-faktor yang mempengaruhi berpengaruh secara selaras dan positif.

\section{Kesimpulan}

Berdasarkan penelitian tentang
pengaruh analisis jabatan dan
pengembangan karir terhadap kinerja
kinerja pegawai Kantor Camat Rantau
Selatan, maka diperoleh kesimpulan
sebagai berikut:

1. Berdasarkan pada hasil analisis hipotesis uji $\mathrm{t}$ yang telah dilakukan pada penelitian ini, sehingga variabel analisis jabatan berpengaruh secara tidak signifikan terhadap kepuasan anggota pada Kantor Camat Rantau Selatan Kabupaten Labuhanbatu.

2. Berdasarkan hasil analisis hipotesis uji $F$ yang telah dilakukan pada penelitian ini, didapat hasil sebagai berikut :

sehingga ada pengaruh yang signifikan antara variabel analisis jabatan, pengembangan karir secara simultan terhadap kinerja karyawan Kantor Camat Rantau Selatan Kabupaten Labuhanbatu.

3. Berdasarkan pada hasil koefisien determinasi $\left(\mathrm{R}^{2}\right)$ yang telah dilakukan pada penelitian ini, didapat hasil bahwa sebesar 13,9\% kinerja karyawan dipengaruhi oleh variabel analisis jabatan, dan pengembangan karir sedangkan sisanya $86,1 \%$ dipengaruhi oleh variabel lain yang tidak diteliti.

\section{Daftar Pustaka}

Yusniarsih dan Suwanto. 2011. Manajemen Sumber Daya Manusia. Erlangga : Jakarta

Swasto, Bambang. 2011. Analisis Jabatan. Jakarta : Salemba Empat

Nugroho dan Kunartinah. 2012. Pengembangan Karir dalam Organisasi. Pustaka Pelajar : Yogyakarta

Syamsuddin, Sadili dan Isanto dkk. 2006. Pengembangan Karir. Jakarta : Rineka Cipta 
Gomes, Luis R, Meija Balkin dan L. Candi Robert. 2007. Tugas dan Tanggung jawab dalam Jabatan. Jakarta : Erlangga

Dessler. 2014. Spesifikasi Sumber Daya Manusia. PT. Gramidia Pustaka Utama : Jakarta

Gomes, Faustino cardiso. 1995. Jenis Analisis Jabatan. Prenhallindo : Jakarta

Robbins. 2002. Tanggung Jawab dalam Bekerja. Jakarta : Salemba Empat

Nawawi. 2005. Tujuan Organisasi. Erlangga : Jakarta

Nurcahyo. 2012. Menyesuaikan Antara Kebutuhan Karyawan dengan Tujuan Perusahaan. Yogyakarta : Pustaka Pelajar

Mangkanegara. 2004. Tujuan Pengembangan Karir. Bayumedia Publishing : Jakarta

Simamora. 2004. Model Pengembangan Karir. Bandung : Alfabeta

Robbins. 2006. Job Performance. Jakarta : Salemba Empat

Sugiono. 2008. Metode Penelitian Kualitatif dan Kuantitatif. CV.Alfabeta : Bandung Arikunto. 2006. Prosedur Penelitian Suatu Pendekatan Praktik. Jakarta : Rineka Cipta

Harsono. 2008. Model-model Pengelolaan Perguruan Tinggi. Yogyakarta : Pustaka Pelajar Sugiono. 2012. Metode Penelitian Kuantitatif dan R\&D. Bandung : Alfabeta

Ghozali. 2009. "Aplikasi Analisis Multivariate dengan Program SPSS" edisi 3. PT.Gramedia Pustaka :

Jakarta 